\title{
Identification of Geo - Hazard Using Pore Pressure Analysis in 'MAC' Field, Niger Delta
}

\author{
Advances in Earth and Environmental Science
}

Research Article

James Sunday Abe*, Ipinmoye Femi Thaddaeus

Department of Applied Geophysics, Federal University of Technology Akure

\author{
* Correspondence authors \\ Abe Sunday James \\ Department of Applied Geophysics \\ Federal University of Technology Akure \\ Ondo State \\ Nigeria
}

Submitted : 12 Nov 2021 ; Published : 30 Nov 2021

\begin{abstract}
Identification of geo-hazard zones using pore pressure analysis in 'MAC'field was carried out in this research. Suite of wireline logs from four wells and RFT pressure data from two wells were utilized. Lithologic identification was done using gamma ray log. Resistivity log was used to delineate hydrocarbon and non-hydrocarbon formations. Well log correlation helps to see the lateral continuity of the sands. Pore pressure prediction was done using integrated approaches. The general lithology identified is alternation of sand and shale units. The stratigraphy is typical of Agbada Formation. Three reservoirs delineated were laterally correlated. Crossplot of Vp against density (Rho) colour coded with depth revealed that disequilibrium compaction is the main overpressure generating mechanism in the field. Prediction of overpressure by normal compaction trend was generated and plot of interval transit time against depth show that there is normal compaction from $250 \mathrm{~m}$ to about $1700 \mathrm{~m}$ on MAC-01, but at a depth of about $1800 \mathrm{~m}$, there was abnormal pressure build up that shows the onset of overpressure. A relatively normal compaction was observed on MAC-02 until a depth of about $2100 \mathrm{~m}$ where overpressure was suspected. The prediction of formation pore pressure using Eaton's and Bower's method to determine the better of the two methods to adopt for pore pressure prediction shows that the pore pressure prediction using Eaton's method gave a better result similar to the acquired pressure in the field. Hence Eaton's method appears to be better suited for formation pore pressure estimation in 'MAC' field. The validation of the pore pressure analysis results with available acquired pressure data affirmed the confidence in the interpreted results for this study.
\end{abstract}

Keywords: Overpressure, Eaton, Bowen, Blowout

\section{Introduction}

The understanding of overpressure in the subsurface is important for drilling safety, exploration risk and reservoir depletion studies [1]. Accurate pore pressure prediction is vital for successful and safe drilling of wells in the Deep and Ultra-Deep offshore area. In the Niger Delta kicks have been observed in permeable zones within the Early Miocene shale, suggesting mud-weights have been set too low as a result of inaccurate predrill pressure prediction [2]. The prevention of drilling mud losses or kicks, the drilling risk assessment in connection with expected formation pressure, the casing design and so on are typical geo-hazard problems associated with prediction and estimation of pore pressure before and during exploration well drilling [3].

High pore pressure fluids are encountered worldwide in formations ranging in ages from Palaeozoic to Cenozoic era and may be encountered in shale-sand sequences and/ or carbonate - evaporate sections at depths ranging from a few $100 \mathrm{~m}$ below the earth's surface to depths exceeding $6100 \mathrm{~m}$. Therefore, as exploration and exploitation of hydrocarbon move into deeper water environment, pore pressure analysis has become an important asset in the team's planning process.
Pore pressure analysis serves as a useful tool in many areas. In exploration, it is useful for detecting presence of hydrocarbon seals, mapping of hydrocarbon pathways, analysing trap configuration and for basin modelling [4]. It also serves as a great tool in drilling as it helps in understanding mechanisms and influences of overpressure development on hydrocarbon accumulation.

Overpressures can be generated by several mechanisms, such as compaction disequilibrium (under compaction), hydrocarbon generation and gas cracking, aqua thermal expansion, tectonic compression, mineral transformations, osmosis, hydraulic head and hydrocarbon buoyancy [5]. One of the major reasons for abnormal pore pressure is abnormal formation compaction. When sediments compact normally, formation porosity is reduced at the same time pore fluid is expelled.

One of the biggest challenge facing the exploration and production industries during exploration of potential hydrocarbon reservoir is overpressure [6]. The pressure related challenges include; loss of circulation, pipe stuck, kick, well control incidents, differential stacking, bit penetration

Adv Earth \& Env Sci; $2021 \quad$ www.unisciencepub.com Volume 2 | Issue 4 
reduction reservoir collapse or damage, all these can cause geo hazard on the field if not properly managed.

Hence, to manage geo hazard such as blow out, damage of the drilling string, kicks, rigs destruction and loss of lives, influx. Proper estimation and prediction of pore pressure, reservoir pressure is needed before commencing drilling activities, during drilling operation and after [7].

The primary aim of pore pressure prediction is to guard against geo-hazard due to majorly overpressure or abnormal pressure. This research work is centred on identification of geo-hazard using pore pressure analysis in the study area with the aid of well data to basically detect, predict and estimate over pressure which could further serve as a tool towards advancement or improvement on safe drilling techniques of hydrocarbon.

\section{Location and Geology of the Study Area}

The Niger delta basin is situated on the continental margin of the Gulf of Guinea between latitude $3^{\circ}$ and $6^{\circ} \mathrm{N}$ and longitude $5^{\circ}$ and $8^{\circ} \mathrm{E}$. The area extent of the Niger delta is about $75000 \mathrm{~km}^{2}$ with a clastic fill of about $12 \mathrm{~km}$. The base map of the study area showing the well locations is in Figure 1. The Niger delta basin is divided into mainly three lithostratigraphic units; the Akata formation (Palaeocene to Recent), Agbada formation (Eocene to Recent) and the Benin (Oligocene to Recent) Formation (Figure 2), which conforms with a lower pro-delta lithofacies, a middle delta front lithofacies and an upper delta top facies respectively.

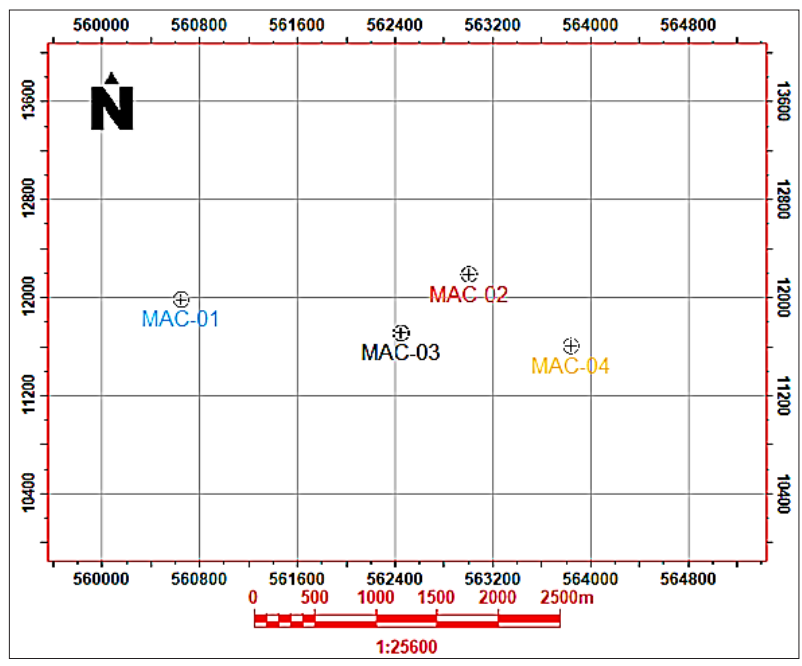

Figure 1: Base Map of 'MAC' Field

The primary source rock is the Upper Akata Formation, the marine-shale facies of the delta, with possible contribution from interbedded marine shale of the lowermost Agbada Formation.

From the Eocene to the present, the delta has prograded southwestward, forming depobelts that represent the most active portion of the delta at each stage of its development [8]. These depobelts form one of the largest regressive deltas in the world with an area of some $300,000 \mathrm{~km}^{2}$, a sediment volume of $500,000 \mathrm{~km} 3$, and a sediment thickness of over $10 \mathrm{~km}$ in the basin depocenter [9-11].

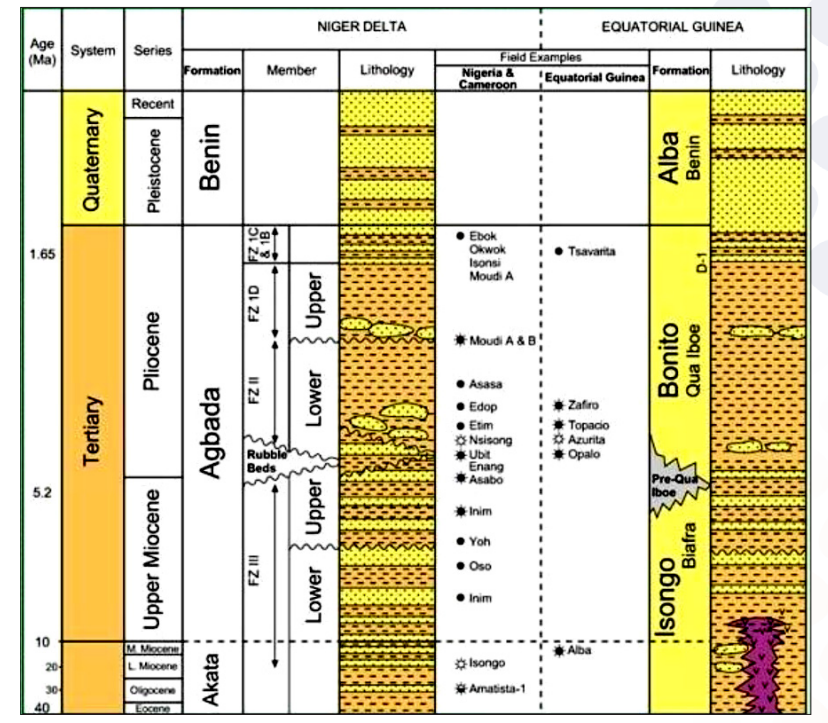

Figure 2: The stratigraphy of the Niger Delta and Equatorial Guinea [9]

\section{Methodology}

\section{Lithology Delineation}

The identification of the lithologic unit was done by using gamma ray log, with zones that having low GR readings (between 0-65 API) as a result of little or no radioactive elements present in them as sand and zones that depicted high GR readings (between 65 - 150 API) as a result of high concentration of radioactive elements present in them as shale.

\section{Delineation of Overburden pressured zones}

A qualitative identification of the overpressure zones was done by observing sonic and density log signatures across each well. This was possible because overpressure zones are characterized by sudden increase in the sonic interval transit time with corresponding decrease in the bulk density.

\section{Porosity Estimation}

The interval transit time obtained from the digitized sonic log was used to estimate the porosity using equation established by Schlumberger (1985) [12]:

$$
\begin{aligned}
& \Phi=0.625\left(1-\Delta t_{\text {ma }} / \Delta t\right) \\
& \text { Where, }
\end{aligned}
$$

$\Delta \mathrm{t}=$ observed interval transit time in $\mu \mathrm{sec} / \mathrm{ft}$,

$\Delta \mathrm{t}_{\text {ma }}=$ interval transit time of the matrix in $\mu \mathrm{sec} / \mathrm{ft}(55.5$ $\mu \mathrm{sec} / \mathrm{ft}$ from literature),

$\Phi=$ porosity.

The porosity estimated was used in calculating the bulk density when estimating the overburden pressure.

\section{Hydrostatic Pressure Estimation}

The hydrostatic pressure was computed by multiplying the normal pressure gradient of the study area by the depth of interest with addition of surface pressure of the atmosphere. A pressure gradient of $0.433 \mathrm{psi} / \mathrm{ft}$ was used. For pure water, the 
value of water pressure gradient is 0.433 pounds second per feet (psi/ $\mathrm{ft})$. The surface pressure of one atmosphere is $14.7 \mathrm{psi}$.

Thus,

$$
\mathrm{P}_{\mathrm{n} / \mathrm{h}}=0.433 * \rho \mathrm{f} * \mathrm{H}+14.7 \mathrm{psi}
$$

Where,

$\mathrm{P}_{\mathrm{n} / \mathrm{h}} \quad=$ Hydrostatic or normal pressure in psi.,

of $\quad=$ Density of the saturating fluid $(1.0 \mathrm{~g} / \mathrm{cc}$ for fresh water),

$\mathrm{H} \quad=$ True vertical depth in feet.

When the formation/pore pressure is lower/greater than hydrostatic/ normal pressure, underpressure/overpressure will occur.

Estimation of Overburden Pressure

The value of the overburden pressure (S) at any depth $\mathrm{H}$ is the combined weight of the fluids and formation above $\mathrm{H}$ and it is given as

$\mathrm{S}_{\mathrm{v}}=[\phi \rho f+(1-\phi) \rho \mathrm{ma}] \mathrm{H} \times 0.4332$

Where,

$\mathrm{S}_{\mathrm{v}}=$ Overburden pressure

$\mathrm{H}=$ true vertical depth in $\mathrm{ft}$

$\phi, \rho f, \rho b$ and $\rho$ ma are respectively the porosity, density of pore fluid, bulk density and grain density or rock matrix density $(2.65 \mathrm{~g} / \mathrm{cc}$ for sandstone /shale from literature).

$0.4332=\mathrm{g} / \mathrm{cc}$ to $\mathrm{psi}$ converter.

Estimation of pore pressure

There are two methods commonly used to determine Pore Pressure from well logs: Eaton method and Bowers method $[13,14]$.

The Eaton's sonic method is quick and directly applicable to estimate Pore Pressure.

Eaton's sonic equation used to compute Pore Pressure, PP is given below [13]:

$\mathrm{PP}=\mathrm{SV}-(\mathrm{SV}-\mathrm{Ph}) *\left(\Delta \mathrm{t}_{\mathrm{n}} / \Delta \mathrm{t}\right)^{\mathrm{n}}$

Using,

$$
\text { Rho: } P_{p}=P_{o b s}-\left(P_{o b s}-P_{h y d}\right) \times\left(\frac{R h o}{R h o_{n}}\right)^{3}
$$

where,

$\mathrm{P}_{\mathrm{obs}} / \mathrm{S}_{\mathrm{v}}=$ Overburden pressure or vertical stress,

$\mathrm{P}_{\mathrm{h}} \quad=$ hydrostatic pressure gradient is assumed as $10 \mathrm{MPa} \mathrm{km}^{-1}$,

$\Delta \mathrm{t}=$ compressional sonic travel time, $\mu \mathrm{sec} / \mathrm{ft}$,

$\Delta \mathrm{t}_{\mathrm{n}} \quad=$ travel time computed from normal compaction trend (NCT), $\mu \mathrm{sec} / \mathrm{ft}$,

$n \quad=$ Eaton's exponent $(\mathrm{n}=3)$.

Rho = density from well log data in $\mathrm{g} / \mathrm{cc}$,

$\mathrm{Rho}_{n}=$ is normal compacted shale density in $\mathrm{g} / \mathrm{cc}$,

Other method used is the Bowers method which employs vertical effective stress (VES).

In compaction disequilibrium conditions, Bowers (1995) proposed an empirically determined method to calculate the effective stress as follows [14]:

$\mathrm{V}=\mathrm{V} 0+\mathrm{A} \sigma \mathrm{B}$

where, $\mathrm{V}$ is the compressional velocity at a given depth and V0 stands for the surface velocity or compressional velocity in the mudline (normally $1500 \mathrm{~m} \mathrm{~s}-1$ ), $\sigma$ represents the VES, and $\mathrm{A}$ and $\mathrm{B}$ are the parameters obtained from calibrating regional offset velocity versus effective stress data.

In unloading conditions, Bowers (1995) proposed the following empirical relation [14]:

$$
V=V_{0}+A\left[\sigma_{\max }\left(\frac{\sigma}{\sigma_{\max }}\right)^{\frac{1}{U}}\right]^{B},
$$

where

$$
\sigma_{\max }=\left(\frac{v_{\max }-1500}{A}\right)^{\frac{1}{B}},
$$

The Bowers normal compaction trend parameters were developed by fitting the Bowers normal compaction trend to know effective stress and seismic velocity.

The values of A and B obtained for Niger Delta after correlation with existing data are 4.5641 and 1.461 respectively.

Where,

$U$ is the unloading parameter.

$\sigma_{\max }$ and $v_{\max }$ represent the values of maximum effective stress and maximum velocity at the onset of unloading, respectively [14].

Establishment of Normal Compaction Trendline (NCT)

This is a linear correlation between properties of shale such as sonic velocity with depth of burial. The normal compaction trendline in this research work was established from the compressional velocity, $\mathrm{Vp} \log$ and Rho. It was generated in the RokDoc package using the reciprocal input log transform of compressional velocity, $\mathrm{Vp}$.

The normal compaction trend is initially estimated using the reciprocal input log transform given in the equation

$$
\frac{1}{V_{p}\left(Z_{m l}\right)}=\frac{1}{V_{p \text { Marix }}}-\left(\frac{1}{V_{p \text { Marix }}}-\frac{1}{V_{p \text { Top }}}\right) * e^{-b^{*} z m n}
$$

Where;

$\mathbf{V} \mathbf{p}_{\text {Top }}$ is the compressional sonic velocity at the surface $(\mathrm{ft} / \mathrm{s})$,

$\mathrm{Vp}_{\text {Matrix }}$ is the compressional sonic velocity at maximum extrapolated $(\mathrm{ft} / \mathrm{s})$,

bis the compaction coefficient $\left(1.5 \times 10^{-4} \mathrm{ft}^{-1}\right)$.

The NCT was iteratively tried until a reasonable trend was picked in relation to the cleanest shale interval.

\section{Estimation of Interval Transit Time in Normally Compacted Shale}

The normal compaction trendline of the transit time can be obtained from the following equation:

$$
\Delta t_{n}=\Delta t_{m}+\left(\Delta t_{m l}-\Delta t_{m}\right) e^{-c Z}
$$

Where;

$\Delta t_{\mathrm{m}}=$ interval transit time in shale matrix in $\mu \mathrm{sec} / \mathrm{ft}$, (ranges between 60 to $176 \mu \mathrm{sec} / \mathrm{ft}$,

From literature but $90 \mu \mathrm{sec} / \mathrm{ft}$ is used in this research), 
$\Delta t n=$ interval travel time in normally compacted shale in $\mu \mathrm{sec} /$ $\mathrm{ft}$,

$\Delta t_{m l}=$ mudline interval travel time in $\mu \mathrm{sec} / \mathrm{ft}$, it is the interval transit time in the mudline at the surface usually $200 \mu \mathrm{sec} / \mathrm{ft}$ in the shale - sandstone area but can be gotten from plot of $\Delta t$ against depth,

$\mathrm{C}=$ compaction constant $(0.000245$ from literature $)$,

$\mathrm{Z}=$ depth in $\mathrm{ft}$.

\section{Results and Discussion}

Figure 3 is a well log correlation panel of wells MAC-01, 03 and 04 oriented in northwest to southeast directions. Figure 4 is an arbitrary correlation of the four wells used for the study. The sand units are generally dirty comprising thin shale interbedding. Three prospective reservoir sands designated as RES-1, RES-2 and RES-3 were identified

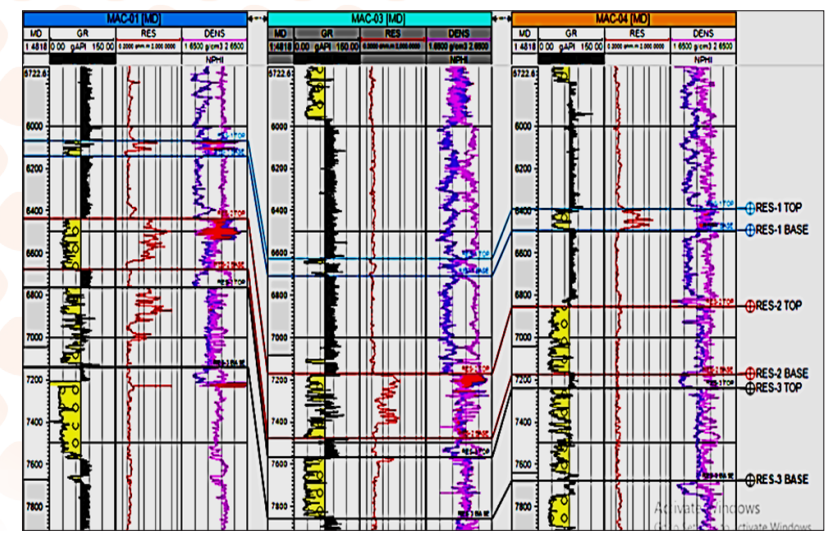

Figure 3: Lithostratigraphic Correlation of MAC-01, 03 and 04 Wells

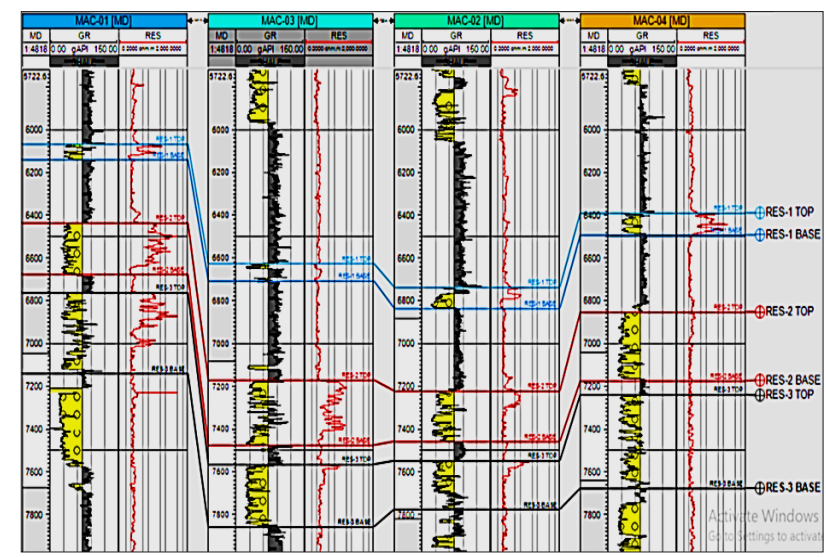

Figure 4: Lithostratigraphic Correlation of MAC-01, 02, 03 and 04 Wells

And correlated across the two wells using gamma ray and resistivity logs. The reservoirs correlated were based on the high resistivity readings and continuity across the sand beds (indicating the presence of hydrocarbon), continuity of the sand units across the wells. All the three reservoirs were observed to be generally clean and comprise thin shale interbedding. The three reservoirs were undulating across the wells with highest gross thickness found in wells MAC-01 and 03 respectively. The delineated sands also decrease in thickness with depth.
This sand-shale sequence typifies the stratigraphy of the NigerDelta basin. From the correlation panels, the analysis of the well section revealed that only reservoir RES-1 has hydrocarbon across all the wells and varies slightly in thickness with some units occurring at greater depth than adjacent units which is probably evidence of faulting.

\section{Overpressure Mechanism}

Estimation of overpressure zones was done by exploiting the cross plot of reservoir and elastic properties. These properties were estimated by utilizing the empirical relationship already established by various authors. Figure 5 shows cross plot of Vp against density (Rho) colour coded with depth. The plot was used to know the two major mechanisms of overpressure (Disequilibrium compaction and Secondary mechanisms). Disequilibrium compaction mechanisms occur as a result of rapid sediment loading unaccompanied by equally rapid dewatering and compaction while secondary mechanisms of overpressure result from the normal sediment loading mechanism that occur as depth of burial increases.

Figure 5 reveals an increase in density and also a corresponding increase in velocity as the depth increases. The highest density and velocity as observed at the deepest depth. This suggest that the mechanism responsible for overpressure in the study field is a typical compaction disequilibrium.

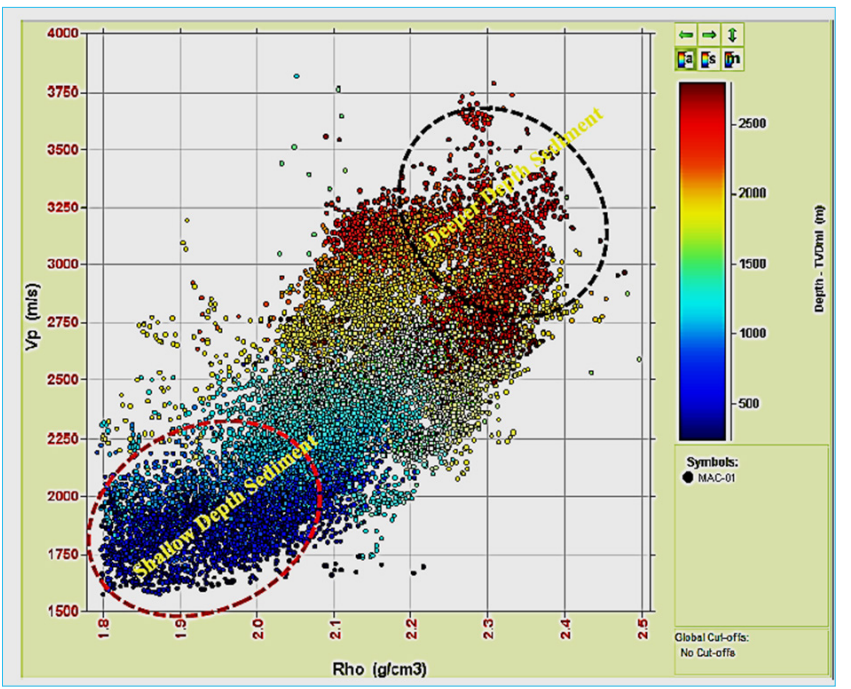

Figure 5: Cross plot of Vp against Density (Rho) colour coded with depth.

\section{Normal Compaction Trend}

Normal compaction trend (NCT) was computed for MAC-01 and 02 wells (Figures 6 and 7). The Normal Compaction Trend represents the best fit line trend of the measured velocity across the transition zone in the low permeable beds [15]. Generally, abnormal pressure build up is common in shale unit, hence, a shale cut-off was applied to eradicate the velocity within the sand interval. This was important to get a good fit of the shale trend within the cleanest shale in the well for normal compaction trend generation. Figure 6 shows the computed NCT for MAC-01 well. It can be observed that there is normal compaction from depth 250 to about $1700 \mathrm{~m}$. This suggest 
that the sediments compact normally but at a depth of 1800 $\mathrm{m}(1.8 \mathrm{~km})$, indicated by the black arrow marks the onset of overpressure in the well. Below this depth was observed a fall below the normal compaction trend line which is due to increase in porosity in the overpressure shale. The depth point where this change begins is known as the top of overpressure.

Figure 7 shows the computed NCT for MAC-02 well. It can be observed that there is relatively normal compaction throughout the well. This suggests that the sediments compact normally. But at a depth of about $2100 \mathrm{~m}(2.1 \mathrm{~km})$, there was a noticeable deviation from normal compaction trend suspected to be an overpressure in the well. There was a fall below the normal compaction trend line which is due to increase in porosity in the overpressure shale.

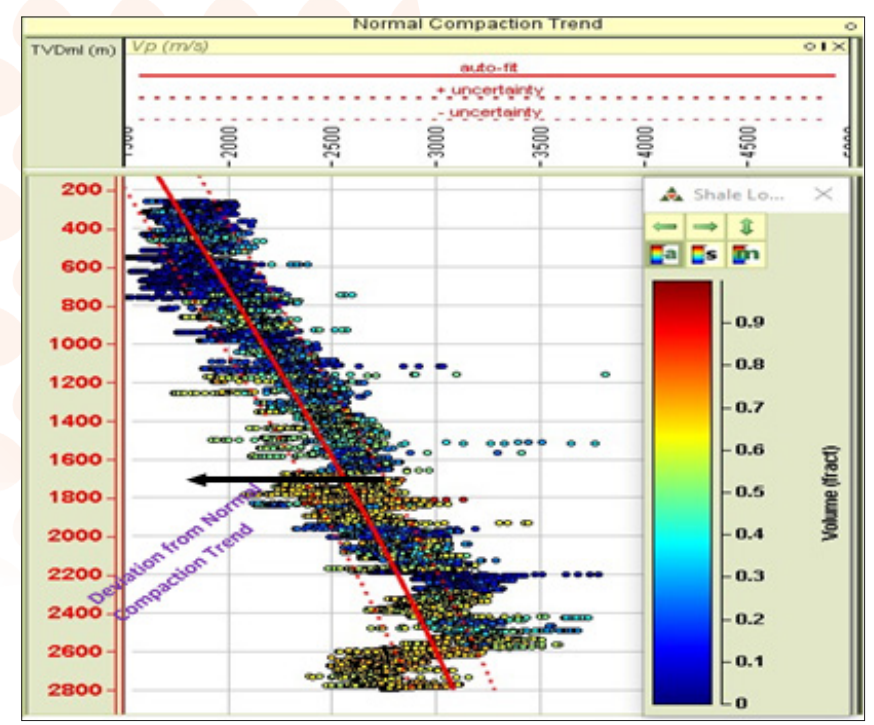

Figure 6: Normal Compaction trend of MAC-01 Well indicating onset of overpressure.

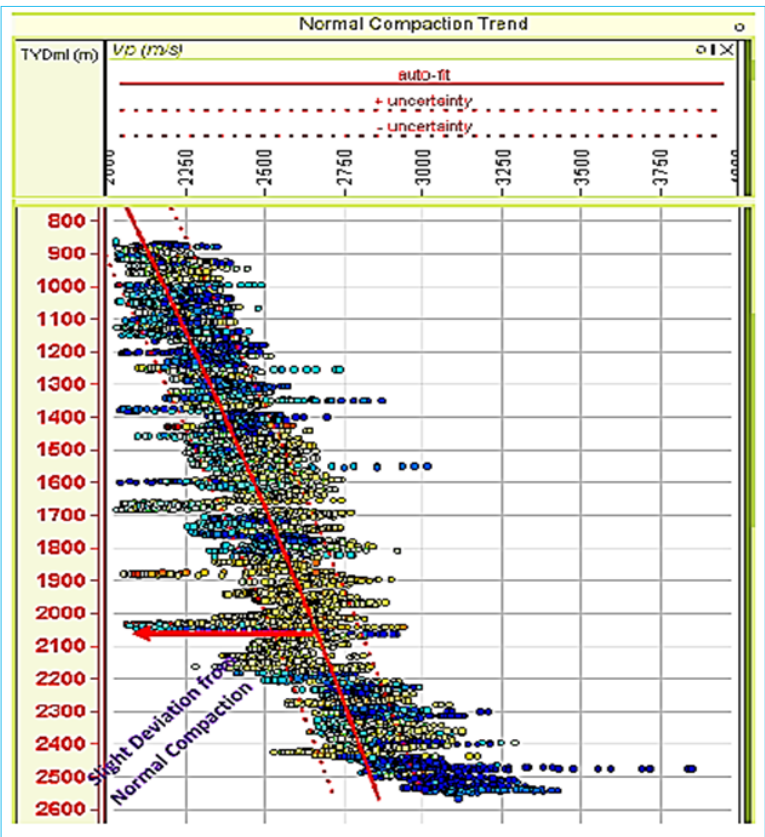

Figure 7: Normal Compaction trend of MAC-02 Well indicating onset of overpressure

\section{Overburden Pressure}

Figures 8 and 9, shows the computed overburden pressure gradient for MAC-01 and 02 wells. Overburden or lithostatic pressure is the pressure or stress of the overlying material weight imposed on a layer of rock. It constituted one of the major parameters required for pore pressure prediction. In this study it was computed using the cumulative bulk density weight above the depth of interest from the bulk density log. The overburden gradient is represented with red line through the displayed density log points.

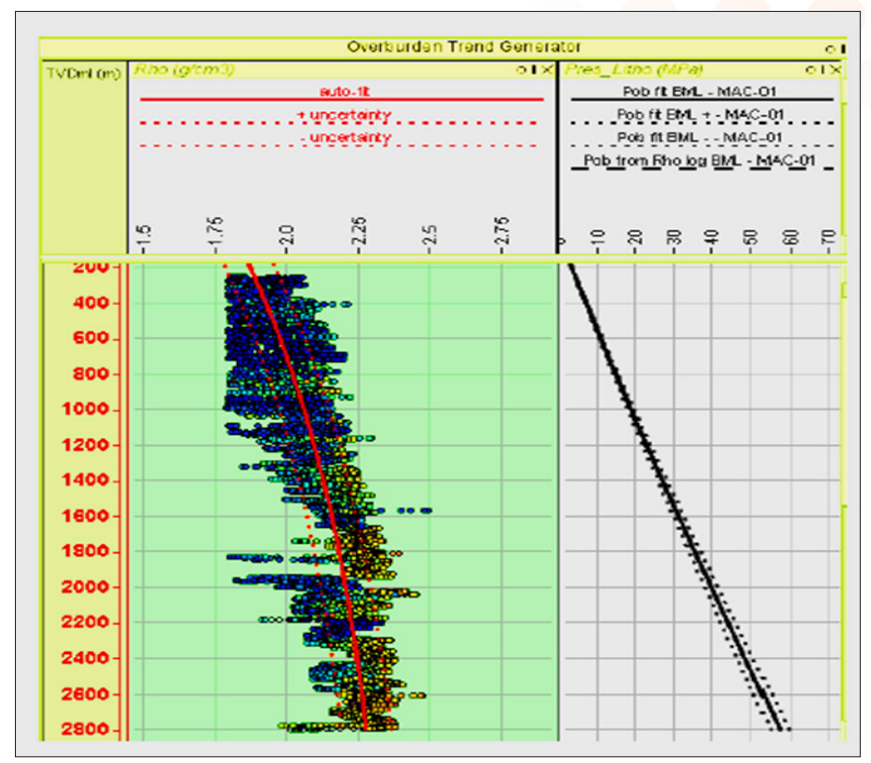

Figure 8: Overburden trend generated from the density log of MAC-01 Well

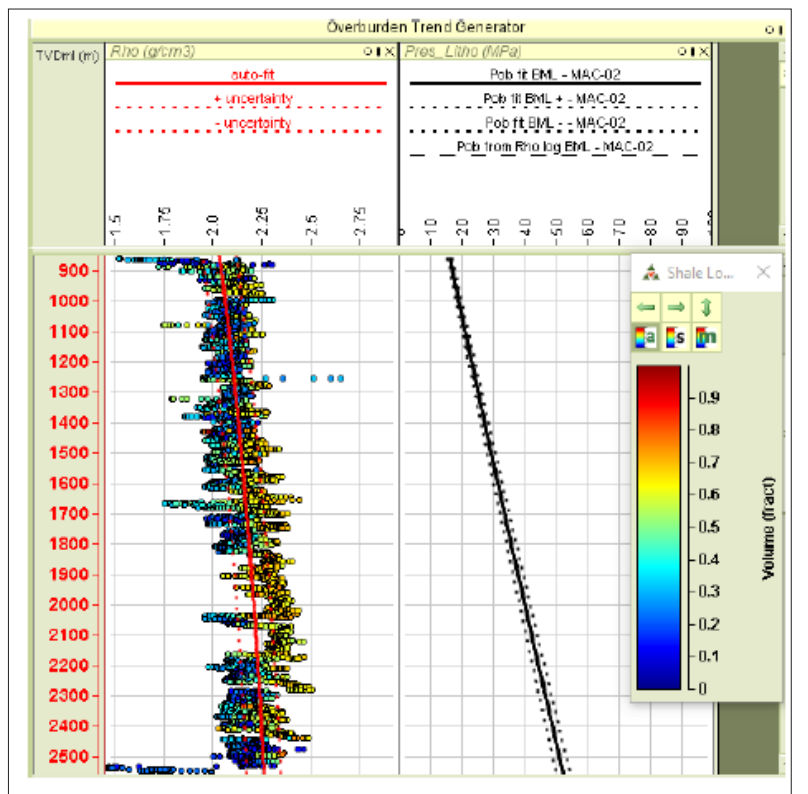

Figure 9: Overburden trend generated from the density log of MAC-02 Well

Pore Pressure Prediction using Interval Transit Time Pore pressure zones were predicted using the plot of interval transit time against depth. Overpressure zones were detected at the depth points in which log signal pattern deviated from the 
trend line. Figures 10 and 11 shows the plot for MAC-01 and 02 wells. For well MAC-01 plot (Figure 10), overpressure zone was delineated at a depth between 1950 and $2000 \mathrm{~m}$. this zone corresponds to shale. Figure 11, shows the plot for well MAC02 . A relatively normal compaction throughout the well was observed. This suggests that the sediments compact normally. The results obtained from this analysis nearly conform to the results gotten from the result of normal compaction trend analysis.

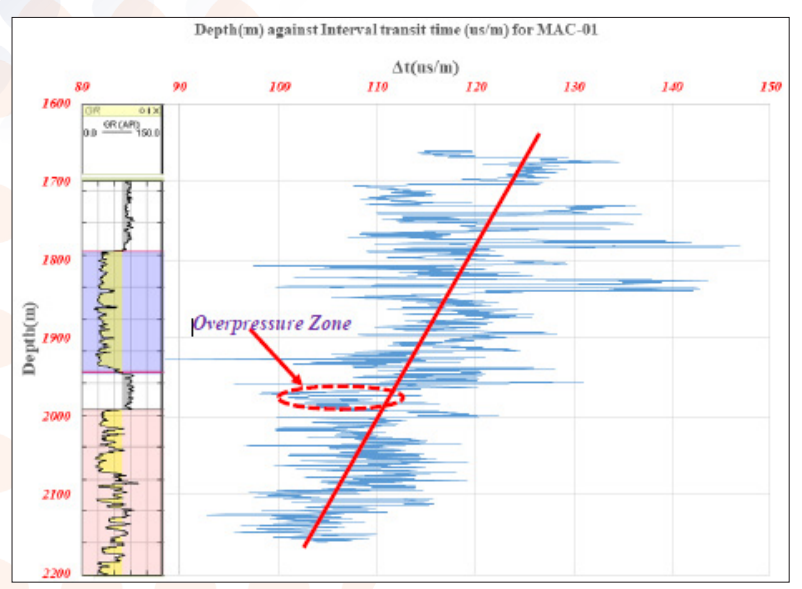

Figure 10: Pore pressure zone prediction using Interval Transit time on MAC-01 Well

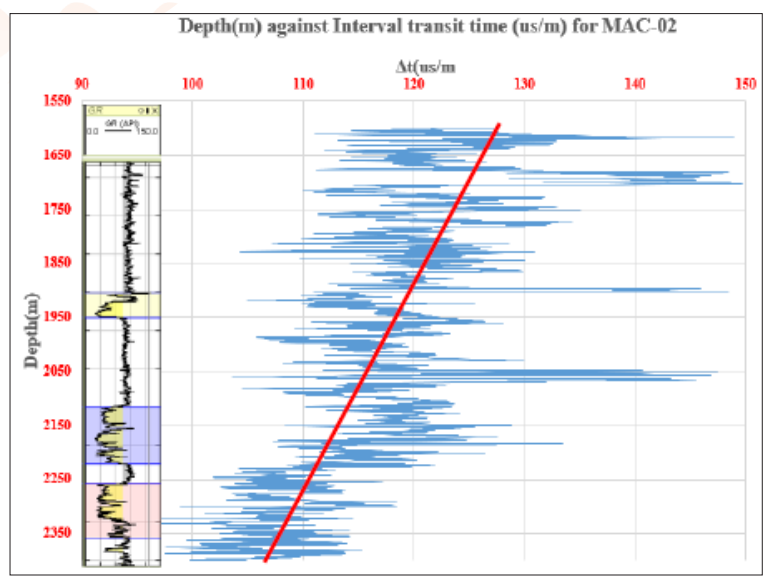

Figure 11: Pore pressure zone prediction using Interval Transit time on MAC-02

Pore Pressure Zone Prediction

The two most used models (Eaton's and Bower's methods) were both adopted for the estimation and prediction of the formation pore pressure in this study. This was also used to establish the technique that will give similar results to the RFT pressure data available for the two wells MAC-01 and 02 utilized for this study. The Eaton's method of formation pore pressure prediction relates effective stress in a well with that of a normally consolidated formation. It also relates the velocity of a normally consolidated formation with the measured velocity to predict formation pore pressure. The method adopts the vertical effective stress generated from a computed normal compaction trend, with the assumption that the formations are basically mechanically compacted, the sediments are at maximum effective stress and the lithology is thick shale

On the other according to Bower, 1995, Bower's method demonstrated the error common with linking pore pressure to the deviation of velocity from computed compaction trend. The method suggested that the observed deviation could be as a result of complex variation in lithology that could cause a significant change in velocity that is not essentially related with pore pressure. To correct this anomaly, Bower proposed a method that calculates effective stress directly from velocity without establishing the compaction trend, which is deducted from overburden stress to get formation pore pressure.

Similarly, the method most times account for the inadequacies associated with pore pressure prediction but often associated with overestimation of pore pressure when compaction disequilibrium is the more prevalent mechanism of over pressure.

Figures 12 and 13 shows the computed formation pore pressure using Eaton's and Bower's methods for MAC-01 and 02 wells. Relating the pore pressure plot using the available RFT pressure data (blue curve) with the predictions done by Eaton (black line) and Bower (red curve), it can be observed that there exist strong similarities between the measured pressure and pressures predicted with Eaton's method than the Bower's method. It can be deduced that Eaton's model will give better results for prediction of an off-setwell pressure regime as informed from the analysis to determine the overpressure mechanism. The result depicts disequilibrium compaction was a prevalent mechanism of over pressure in the study field.

Validation of overpressure and pore pressure zones identified from the integrated approaches used in this study was finally done. This was done by plotting the available RFT pressure data wells MAC-01 and 02. Figures 14 and 15, shows the computed plots for MAC-01 and 02 wells. Overpressure zones was identified at a depth of about $1900 \mathrm{~m}$ on MAC-01 well and a consistent normal compaction was observed for on MAC-02 well. This affirmed the confidence in the interpreted results for this study.

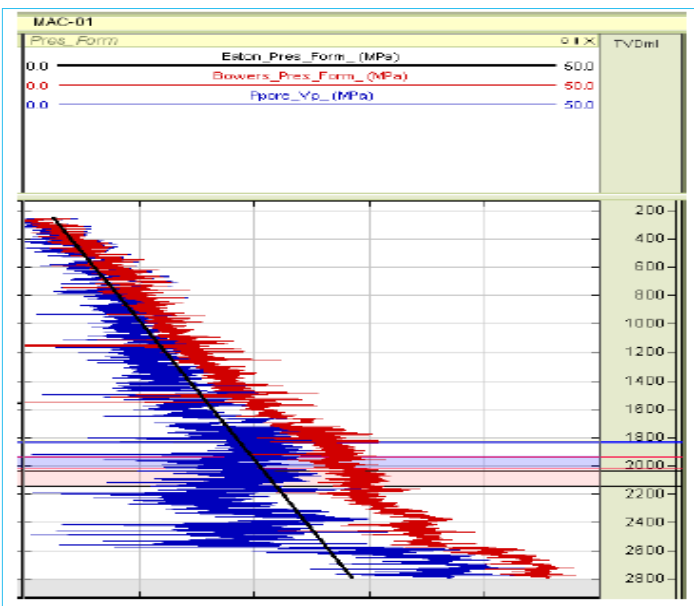

Figure 12: Results of Bower's and Eaton's pressure models for MAC-01 Well 


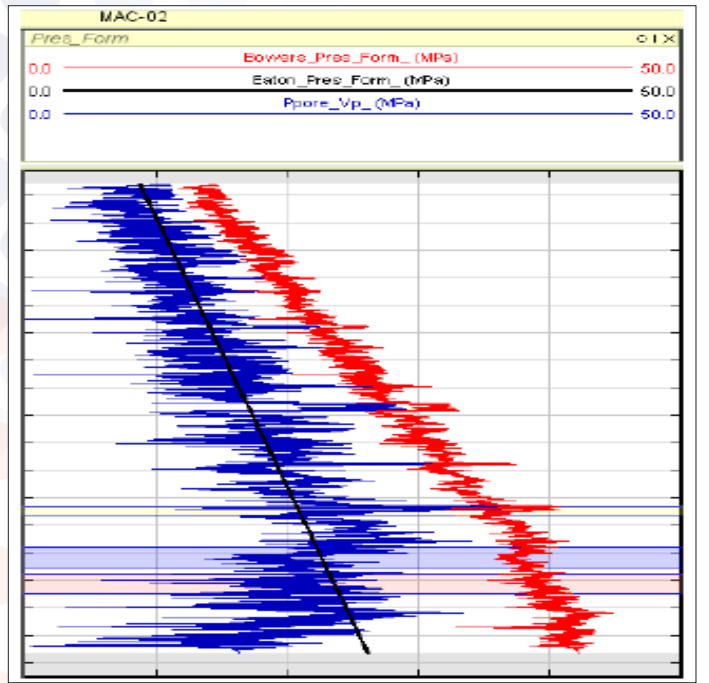

Figure 13: Results of Bower's and Eaton's pressure models for MAC-02 Well

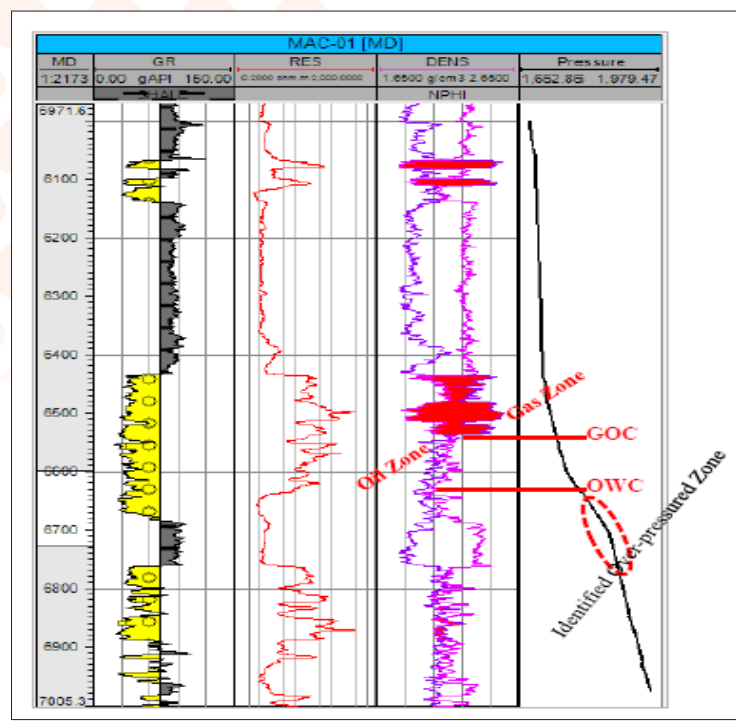

Figure 14: Pressure Data Plot for Validation of Results for MAC-02 Well

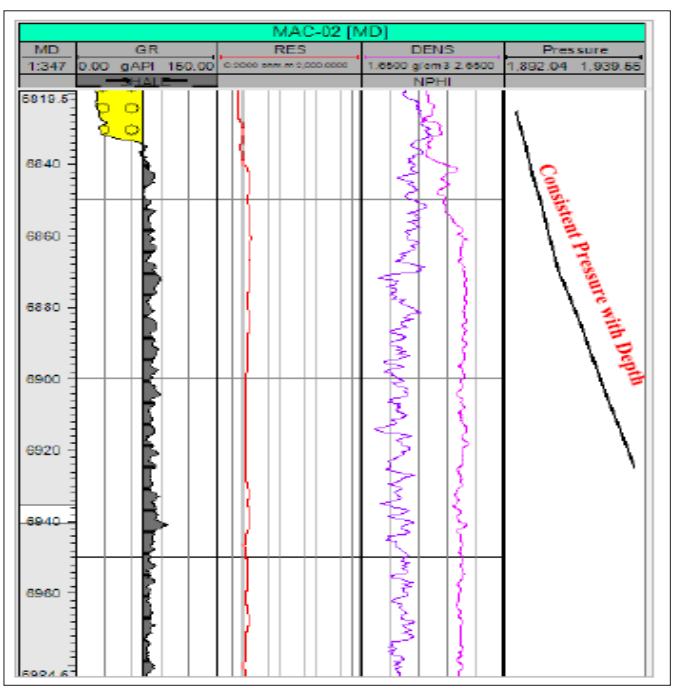

Figure 15: Pressure Data Plot for Validation of Results for MAC-02 Well

\section{Conclusion}

Pore pressure prediction in 'MAC' field, offshore Niger Delta was carried out in this research. Gamma ray was used for lithologic identification. Resistivity log was used to delineate hydrocarbon and non-hydrocarbon formations. Well log correlation helps to see the lateral continuity of the sand. The general lithology is alternation of sand and shale units. The sand units decrease in thickness with depth while the shale units' increase. The croossplot of Vp against density (Rho) colour coded with depth helps to understand the mechanism of overpressure within the study field. The result of this analysis suggest that disequilibrium compaction is the main overpressure generating mechanism in the field. Prediction of overpressure by normal compaction trend generated shows that there is normal compaction from depth 250 to about $1700 \mathrm{~m}$ on MAC-01 well at a depth of about $1800 \mathrm{~m}$, there was abnormal pressure build up that shows the onset of overpressure. A relatively normal compaction was observed on MAC-02 well until a depth of about $2100 \mathrm{~m}$ where overpressure was suspected.

Similarly, the pore pressure zones predicted using the plot of interval transit time against depth show almost the same results like that of normal compaction trend analysis. The prediction of formation pore pressure using Eaton's and Bower's method to determine the better of the two methods to adopt for pore pressure prediction in this field was done. The pore pressure prediction using Eaton's method gave a better results similar to the acquired pressure in the field. Hence Eaton's method appears to be better suited for formation pore pressure estimation in 'MAC' field. The validation of the pore pressure analysis results with available acquired pressure data affirmed the confidence in the interpreted results for this study. From the result of this study, a special drilling design should be adopted for in order to mitigate the potential risk posed by the overpressure zones.

\section{References}

1. Opara AI, Onuoha KM (2009) Overpressure and trap integrity studies in parts of the Onshore, Niger Delta Basin: implications for hydrocarbon exploitation and prospectivity. SPE J 240-242.

2. Babu S, Sircar A (2011) A comparative study of predicted and actual pore pressures in Tripura. Indian Journal of Petroleum Technology and Alternative Fuels 2: 150-160.

3. Huffman AR (2002) The future of pressure prediction using geophysical methods. In A.R. Huffman \& G.I. Bowers, eds. Pressure regimes in sedimentary basins and their prediction. AAPG, Memoir 76: 217-233.

4. Ismail AR (2010) Formation Pressures. UTM Open Courseware for Petroleum Engineering Dept. Faculty of Petroleum \& Renewable Energy Eng. University Teknologi, Malaysia 5.

5. Dutta NC (2002) Geopressure prediction using seismic data: Current status and road ahead: Geophysics 67: 20122041.

6. Bera P (2010) Estimation of pore pressure from well logs: A theoretical analysis and case study from an offshore 
basin, North Sea. $8^{\text {th }}$ Biennial International Conference and Exposition on Petroleum Geophysics. Hyderabad.

7. Law BE, Spencer CW (1998) Abnormal pressure in hydrocarbon environments, in B.E. Law, G. F. Ulmishek, and V. I. Slavin, eds., Abnormal pressure in hydrocarbon environments: $A A P G$ Memoir 70: 1-11.

8. Doust H, Omatsola E (1990) Niger delta, In: J. D. Edwards and P. A. Santogrossi, eds., Divergent/Passive Margin Basins, AAPG Memoir 48: 239-248.

9. Kulke H (1995) Regional Petroleum Geology of the World. Part II: Africa, America, Australia and Antarctica: Berlin, Gebrüder Borntraeger 143-172.

10. Hospers J (1965) Gravity field and structure of the Niger Delta, Nigeria, West Africa: Geological Society of American Bulletin 76: 407-422.

11. Ekweozor CM, Daukoru EM (1984) Petroleum source bed evaluation of Tertiary Niger Delta--reply: American Association of Petroleum Geologists Bulletin 68: 390394.

12. Schlumberger (1985) Log Interpretation, Principles and Application. Schlumberger Educational Services, Texas 2-1.

13. Eaton BA (1975) The Equation for Geopressure Prediction from Well Logs, paper SPE 5544 presented at the SPE Annual Technical Conference and Exhibition, Dallas, TX, September 28 - October 1.

14. Bowers GL (1995) Pore pressure estimation from velocity data: Accounting for overpressure mechanisms besides undercompaction. Society of petroleum Engineer Drilling and Completions 10: 89-95.

15. Shaker S (2007) Calibration of Geopressure prediction using Normal Compaction Trend: Perception and Pitfall: CSEG Recorder 32: 29-35.

Copyright: (O2021 Abe Sunday James. This is an open-access article distributed under the terms of the Creative Commons Attribution License, which permits unrestricted use, distribution, and reproduction in anymedium, provided the original author and source are credited. 